\title{
焼結過程における微量塩素の層内挙動および 排ガスダイオキシン類濃度に及ぼす影響
}

\author{
川口 尊三* ·松村 勝* · 細谷 陽三*2 . 葛西 栄輝*3 \\ Behavior of Trace Chlorine in Sintering Bed and Its Effect on \\ Dioxins Concentration in Exhaust Gas of Iron Ore Sintering \\ Takazo Kawaguchi, Masaru Matsumura, Yozo Hosotani and Eiki KasaI
}

Synopsis : Suppression of dioxins emission for iron ore sintering is one of the most important and urgent needs. To the purpose, the basic research for the title is necessary. Sinter pot tests of sinter mixture adding $\mathrm{Cl}$ content were carried out, and the results obtained are as followed. (1) 20-40 mass $\%$ of $\mathrm{Cl}$ content in sinter mixture stays in sintercake. $20-40$ mass $\%$ of volatile $\mathrm{Cl}$ content traps on raw material in sinter bed, while $60-80$ mass $\%$ of that discharges to exhaust gas without trapping raw material. Trapped $\mathrm{Cl}$ content in raw material of sintering bed partly vaporizes again and partly stays at the sintering reaction. The volatile $\mathrm{Cl}$ content is mainly composed of metal-chloride such as $\mathrm{NaCl}, \mathrm{KCl}$ and etc. (2) Dioxins concentration in exhaust gas is proportional to $\mathrm{Cl}$ content added to sinter mix by under $500 \mathrm{mg} / \mathrm{kg}$. Source of $\mathrm{Cl}$ content in term of kinds of chemical compond also affects on dioxins concentration in exhaust gas. $\mathrm{KCl}$, poly-vinyl-chloride, $\mathrm{NaCl}, \mathrm{CaCl}_{2}$, high $\mathrm{Cl}$ ore are rank in order of much concentration of dioxins. Volatile $\mathrm{Cl}$ content and organic content are effevtive factors of dioxins occurrence. The dioxins concentration in the experimental case of high $\mathrm{Cl}$ content at upper layer is more than those in the case of uniform $\mathrm{Cl}$ content, but in the case of high $\mathrm{Cl}$ content at lower layer the dioxins are as same as those.

Key words: sintering process; chlorine content; dioxins concentration; pot test; $\mathrm{KCl} ; \mathrm{NaCl} ; \mathrm{PVC} ; \mathrm{CaCl}_{2}$.

\section{1. 緒言}

焼結鉱製造において排出ダイオキシン量の低減は重要か つ緊急な課題であり，多大の努力がはらわれているが，そ の生成挙動が十分に解明されているとは言いがたい。細谷 ら ${ }^{1)}$ は焼結鍋実験において配合原料に試薬を用い塩素 $(\mathrm{Cl})$ 成分を添加することによって排出ダイオキシン量が増加す ることを確認しているが， $\mathrm{Cl}$ 成分を含むダスト類などの 雑原料を配合した鍋実験では，原料中 $\mathrm{Cl}$ 濃度と排ガスダ イオキシン量との相関を明確にできていない。原料中の $\mathrm{Cl}$ 成分がダイオキシン生成に関連するであろうことは容 易に想像されるが， Cl成分の濃度および化合物形態の排 ガスダイオキシン濃度に及ぼす影響などの定量的評価に は, 従来より精度の高い実験解析が必要と思われる。そこ で，著者ら ${ }^{2}$ は焼結過程におけるダイオキシン定量評価の ための焼結鍋試験方法および成分定量方法について検討 し，有効な手法や条件を確立した。
焼結過程における $\mathrm{Cl}$ の挙動研究については，原料中に 塩化物を添加する脱 $\mathrm{Na}$, 脱 $\mathrm{K}$, 脱 $\mathrm{Zn}$ に関する研究 ${ }^{3,4)}$, 還 元粉化性改善に関する研究 ${ }^{5-10)}$ が報告されているが, 微量 Clの挙動についてはあまり論述されていない。最近, 細 谷ら ${ }^{11)}$ は焼結鍋実験において焼成を中断することによっ て，焼結層高さ方向のダイオキシン濃度および $\mathrm{Cl}$ 濃度分 布を調査し，これらの挙動について解明を試みている。葛 原ら ${ }^{12}$ は焼結原料層での $\mathrm{HCl}$ 吸収挙動の基礎実験を報告し ている。

本報告では $\mathrm{Cl}$ 成分を含有する試薬を配合原料に添加し た焼結鍋実験を実施し，焼結過程における $\mathrm{Cl}$ 成分の焼結 層内挙動および排ガスダイオキシン(P5CDFs)との関係に ついて考察を行った。

平成13年9月7日受付 平成 13 年 10 月 11 日受理 (Received on Sep. 7, 2001; Accepted on Oct. 11, 2001)

* 烧結ダイオキシン類低減研究会 (SDD研究会) (The Collaborative Research Project for Suppression of Dioxin Emissions from the Sintering Process (SDD Project)); 住友金属工業（株）総合技術研究所 (Corporate Research \& Development Laboratories, Sumitomo Metal Industries, Ltd., 16-1 Oaza-Sunayama Hasakimachi Kashimagun Ibaraki-ken 314-0255)

*2 焼結ダイオキシン類低減研究会 (SDD 研究会) (The Collaborative Research Project for Suppression of Dioxin Emissions from the Sintering Process (SDD Project)); 新日本製鐵（株）鉄鋼研究所 (Steel Research Laboratories, Nippon Steel Corp.)

*3 烧結ダイオキシン類低減研究会 (SDD研究会) (The Collaborative Research Project for Suppression of Dioxin Emissions from the Sintering Process (SDD Project)); 東北大学多元物質科学研究所 (Institute of Multidisciplinary Research for Advanced Materials, Tohoku University) 


\section{2. 実験方法}

\section{$2 \cdot 1$ 実験装置および方法}

内径 $300 \mathrm{~mm}$ の焼結鍋試験装置を使用し配合原料 $54.9 \mathrm{~kg}$ (乾燥質量) 一定の原料条件で，焼成排ガス風量が 1.3 $\mathrm{Nm}^{3} / \mathrm{min}$ 一定となるよう制御して焼成実験を実施した。焼 成時間は $35 \mathrm{~min}$ 一定とした。焼結配合原料については水溶 と非水溶に分離して $\mathrm{Cl}$ 成分を定量した。また, 焼成後の 焼結ケーキを上層, 中層, 下層の3 層に分割して $\mathrm{Na}, \mathrm{K}, \mathrm{Cl}$ 成分を各々定量した。さらに, 排ガス配管内にガス採取捕 集瓶をセットし，定量分析により排ガス $\mathrm{Cl}$ 濃度およびダ イオキシン(P5CDFs)濃度を測定した。なお，実験手法， 分析手法および同精度については前報2に詳述した。

\section{$2 \cdot 2$ 配合原料条件と添加 $\mathrm{Cl}$ 試薬および添加 $\mathrm{Cl}$ 量}

Table 1 に示される標準的な鉄鉱石, 副原料, 返鉱および 粉コークスを用い，ダスト類やスケールなどの雑原料を除 くモデル的な配合原料を準備し, 直径 $1000 \mathrm{~mm}$ のドラムミ キサーで $2 \mathrm{~min}$ 間混合した後, $\mathrm{Cl}$ 成分含有の試薬水溶液ま たは圧延油を造粒用水分に混合したものを添加し，5 min 間造粒して㬰験用原料とした。実験条件を Table 2 に示す。 添加する試薬として, $\mathrm{NaCl}$ 水溶液, $\mathrm{KCl}$ 水溶液, $\mathrm{CaCl}_{2}$ 水 溶液およびPVC（塩化ビニールポリマー）試薬の懸濁水 を用いた。添加 $\mathrm{Cl}$ 量としては $200 \mathrm{mg} / \mathrm{kg}$ を基準に $500 \mathrm{mg} / \mathrm{kg}$ も実験した。また，別途， $\mathrm{Cl}$ 成分を多く含む鉄鉱石単味 の配合条件でも実験を行い，鉄鉱石由来の $\mathrm{Cl}$ 成分につい ても検討した。この場合，配合原料の Cl濃度を $260 \mathrm{mg} / \mathrm{kg}$ $(\mathrm{Cl}$ 試薬 $200 \mathrm{mg} / \mathrm{kg})$ を選定したが, 鉱石含有の $\mathrm{Cl}$ だけで は $220 \mathrm{mg} / \mathrm{kg}$ と計算されたので， $40 \mathrm{mg} / \mathrm{kg}$ の $\mathrm{Cl}$ 量を $\mathrm{KCl}$ 水 溶液で補填して Cl 量を合わせた。圧延油は $\mathrm{Cl}$ 成分を含有 しない牛脂をべースにしたもので, 原料中油分の排ガスダ

Table 1. Blending condition of sinter mixture at pot test. (mass\%) (Sinter: $\mathrm{CaO}=9.0, \mathrm{SiO}_{2}=4.6, \mathrm{Al}_{2} \mathrm{O}_{3}=$ $1.9, \mathrm{MgO}=1.3 ; \operatorname{mass} \%)$

\begin{tabular}{cc|cc}
\hline Brand & Ratio & Brand & Ratio \\
\hline Ore A & 25.9 & Serpentine & 1.1 \\
Ore B & 18.5 & Dolomite & 1.9 \\
Ore C & 11.1 & Limestone & 11.1 \\
Ore D & 7.4 & Return fine & 14.8 \\
Ore E & 7.4 & Sum & 100 \\
Iron sand & 0.7 & Coke & 4.0 \\
\hline
\end{tabular}

イオキシン濃度に及ぼす複合的影響を調査するために，一 部のケースにおいて，500 mg/ $\mathrm{kg}$ 量を温水に混合させて添 加した。なお，基本条件として配合原料は焼結鍋内では均 一となるように装入した。

\section{$2 \cdot 3$ 焼結層高さ方向の原料 $\mathrm{Cl}$ 濃度偏在実験}

焼結層内高さ方向の特定部分だけ試薬 $\mathrm{Cl}$ を添加し $\mathrm{Cl}$ 成 分を偏在させることによって，層内における $\mathrm{Cl}$ 成分およ びダイオキシンの挙動をより明確にする実験を実施した。 配合原料全体に対する試薬 $\mathrm{Cl}$ の添加量が $200 \mathrm{mg} / \mathrm{kg}$ （配合 原料 $\mathrm{Cl}$ は $260 \mathrm{mg} / \mathrm{kg}$ ) を前提として, 試薬添加 $\mathrm{Cl}$ が層内で 均一に分布するように添加したケースを基準に，上部 $1 / 3$ 層犬゙け $600 \mathrm{mg} / \mathrm{kg}$ の試薬 $\mathrm{Cl}$ 添加ケース，下部 1/3 層犬゙け 600 $\mathrm{mg} / \mathrm{kg}$ の試薬 $\mathrm{Cl}$ 添加ケースを設定し, 比較検討実験を実施 した。添加 $\mathrm{Cl}$ 試薬には $\mathrm{CaCl}_{2}$ と $\mathrm{NaCl}$ を選定した。さらに， 添加 $\mathrm{Cl}$ 試薬に $\mathrm{PVC}$ を選定して配合原料全体に対する添加 $\mathrm{Cl}$ 量が $500 \mathrm{mg} / \mathrm{kg}$ （配合原料 $\mathrm{Cl}$ は $560 \mathrm{mg} / \mathrm{kg}$ ）を前提に同様 の比較実験も実施した。

\section{4 焼結鍋焼成中断実験}

焼結過程における揮散 $\mathrm{Cl}$ 成分の焼結層内での挙動はダ イオキシン生成の機構解明にとって重要である。この挙動 は排ガス $\mathrm{Cl}$ 成分の時間変化パターン解析からも推察可能 であるが, 測定精度上の難点もあり ${ }^{3)}$, 直接的手法すなわ ち焼結過程を中断して, $\mathrm{Cl}$ 成分定量值からの解析も試み た。鍋中断実験については前述の報告 ${ }^{11)}$ があり，すなわち 鍋風箱部から $\mathrm{N}_{2}$ ガスを逆入させ焼結層を冷却保存させる 手法が紹介されている。この手法は焼結層内の燃焼を素早 く中断し, 乾燥帯と燃焼帯の境界部におけるダイオキシン 濃度分布測定の点では優れているが, 逆流 $\mathrm{N}_{2}$ ガスによる Cl成分揮散の影響も懸念される。そこで, 異なる手法で の確認を目的として，以下の鍋中断実験手法を用いた。す なわち，焼結鍋への原料装入時に碇状の鉄製治具を焼結原 料層に埋め込み，また別途，燃焼前線の位置を判定するた めの熱電対を焼結原料層に埋め込み，通常の点火焼成を 行った。そして, 燃焼前線が所定の位置に到達したと判定 された時に送風機を停止し，碇状の鉄製治具ともども焼結 ケーキを上部につり上げ，焼結ケーキ部と焼結原料部に分 離し，それぞれ別個に容器に移し大気䨌囲気で泠却した。

Table 2. Test condition of adding $\mathrm{Cl}$ content, adding $\mathrm{Cl}$ source in sinter mixture and $\mathrm{Cl}$ segregation in sinter bed. $(\mathrm{mg} / \mathrm{kg})$

\begin{tabular}{|c|c|c|c|c|c|c|}
\hline \multirow[t]{2}{*}{ Ore } & \multirow{2}{*}{$\begin{array}{c}\text { adding } \mathrm{Cl} \\
\text { reagent }\end{array}$} & \multirow{2}{*}{$\begin{array}{c}\text { adding } \mathrm{Cl} \\
\text { content }\end{array}$} & \multicolumn{3}{|c|}{ Adding Cl segregation in bed } & \multirow{2}{*}{$\begin{array}{c}\text { Cl content } \\
\text { of sinter mixture }\end{array}$} \\
\hline & & & upper layer & middle layer & lower layer & \\
\hline \multirow{5}{*}{ Base Ore } & no addition & 0 & 0 & 0 & 0 & 60 \\
\hline & $\mathrm{KCl}$ & \multirow{4}{*}{200} & \multirow{4}{*}{200} & \multirow{4}{*}{200} & \multirow{4}{*}{200} & \multirow{9}{*}{260} \\
\hline & $\mathrm{NaCl}$ & & & & & \\
\hline & $\mathrm{CaCl} 2$ & & & & & \\
\hline & PVC & & & & & \\
\hline Rich Cl Ore & $\mathrm{KCl}$ & 40 & $\overline{40}$ & 40 & 40 & \\
\hline \multirow{8}{*}{ Base Ore } & $\mathrm{NaCl}$ & \multirow{4}{*}{200} & 600 & 0 & 0 & \\
\hline & & & 0 & 0 & 600 & \\
\hline & $\mathrm{CaCl} 2$ & & 600 & 0 & 0 & \\
\hline & & & 0 & $\overline{0}$ & 600 & \\
\hline & $\mathrm{NaCl}$ & 500 & 500 & 500 & 500 & \multirow{4}{*}{560} \\
\hline & \multirow{3}{*}{ PVC } & \multirow{3}{*}{500} & 500 & 500 & 500 & \\
\hline & & & 1500 & 0 & 0 & \\
\hline & & & 0 & 0 & 1500 & \\
\hline
\end{tabular}




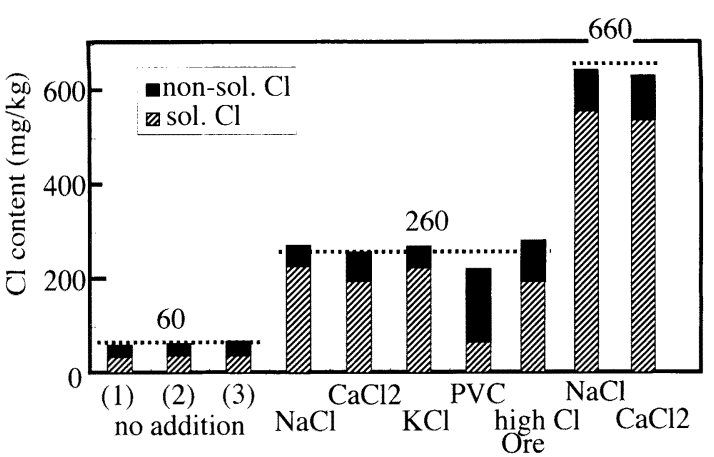

Fig. 1. $\mathrm{Cl}$ content in sinter mixture for pot test.

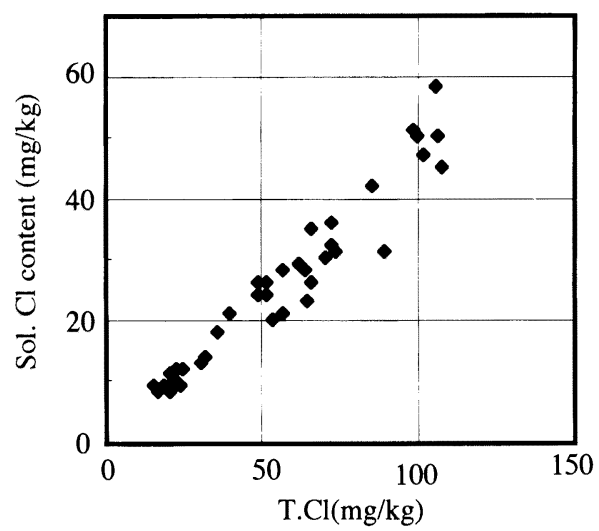

Fig. 2. Relation between sol.Cl and total. $\mathrm{Cl}$ in sintercake.

この場合，焼結原料は鉄製容器に薄く拡げることにより鉄 板吸熱から高い冷却速度が得られ，中断以降の $\mathrm{Cl}$ 成分の 揮散を低く抑制することができる。焼結原料は湿潤帯，乾 燥帯の区別なく回収され, 縮分して $\mathrm{Cl}$ 量の定量分析を 行った。一方, 焼結ケーキは治具を外し落下試験機で 4 回 落下させることで破砕し, 粒径別に $\mathrm{Cl}$ 成分の定量を行っ た。中断時期は, 燃焼前線が層半分まで到達した時, グ レート到達直前時とした。なお，この中断実験には配合原 料として実機焼結機の配合原料を使用した。

\section{3. 実験結果}

\section{1 配合原料と焼結ヶーキの水溶 $\mathrm{Cl}$ 成分と非水溶 $\mathrm{Cl}$ 成 分の構成割合}

Fig. 1 に配合原料の $\mathrm{Cl}$ 分析值を示す。試薬 $\mathrm{Cl}$ が無添加の 場合の $\mathrm{T} . \mathrm{Cl}$ （水溶 $\mathrm{Cl}$ と非水溶 $\mathrm{Cl}$ の合計值）は $60 \mathrm{mg} / \mathrm{kg}$ で, 試薬 $\mathrm{Cl} 200 \mathrm{mg} / \mathrm{kg}$ 添加した場合の T.Clは $260 \mathrm{mg} / \mathrm{kg}$ で, また Cl源を $600 \mathrm{mg} / \mathrm{kg}$ 添加した場合の T.Clは $660 \mathrm{mg} / \mathrm{kg}$ で, 設定どおりの条件を確認できた。また, 水溶 $\mathrm{Cl}$ と非水溶 $\mathrm{Cl}$ の構成割合についてみると, 添加した無機物の $\mathrm{NaCl}$, $\mathrm{KCl}, \mathrm{CaCl}_{2}$ は大部分が水溶 $\mathrm{Cl}$ として検出され，有機物の PVCは非水溶 $\mathrm{Cl}$ である。Fig. 2 に焼結ケーキにおける T.Cl と水溶 $\mathrm{Cl}$ の関係を示すが比例関係が認められ, 焼結ケー キの Cl成分の $45 \mathrm{mass} \%$ が水溶で, 残る $55 \mathrm{mass} \%$ が非水溶

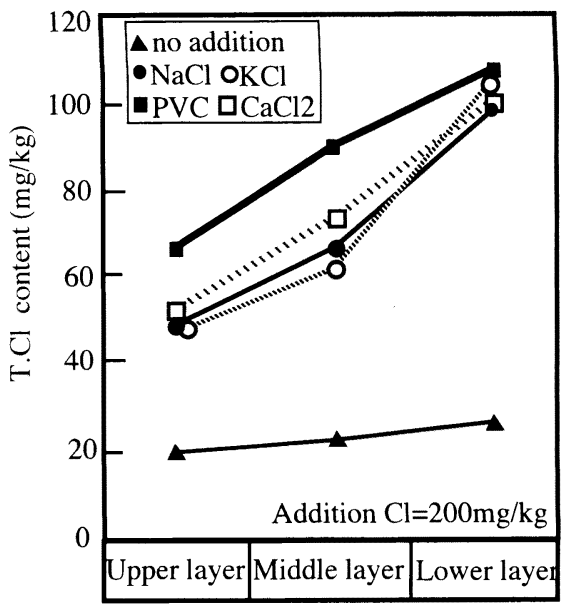

Fig. 3. Total $\mathrm{Cl}$ content in sintercake along vertical direction of sintering bed.

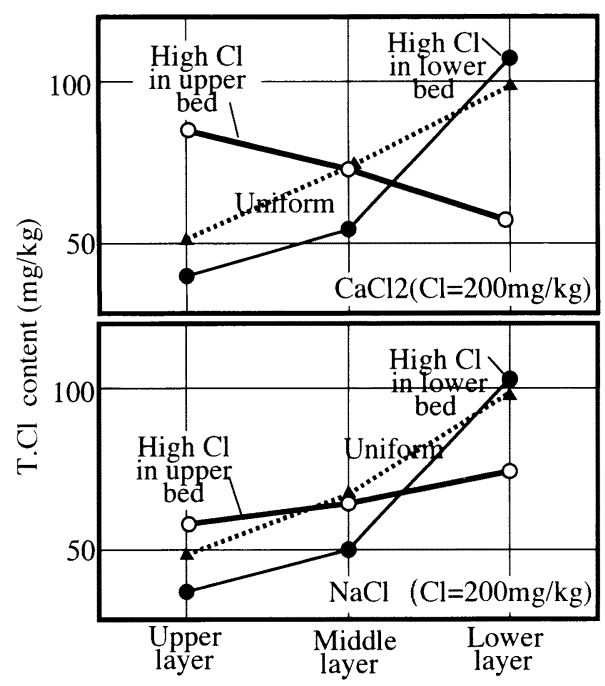

Fig. 4. Total $\mathrm{Cl}$ content in sintercake along vertical direction under test condition of $\mathrm{Cl}$ segregation.

である。一方，Fig. 1に示す配合原料の非水溶 $\mathrm{Cl}$ は 10 30 mass\%で，焼結ケーキの $\mathrm{Cl}$ 成分は配合原料よりも水溶し にくいことがわかる。

\section{$3 \cdot 2$ 焼結ケーキ高さ方向の Cl成分濃度分布}

Fig. 3 に焼結ケーキを上層, 中層, 下層に分割して採取 し，各層の $\mathrm{Cl}$ 成分を定量した結果を示す。上層よりも中 層, 中層よりも下層の方が $\mathrm{Cl}$ 成分は高い傾向が認められ る。この傾向は配合原料へ試薬 $\mathrm{Cl}$ を添加しない場合では わずかであるが, 試楽 $\mathrm{Cl}$ を添加した場合では試薬 $\mathrm{Cl}$ の種 類に関係なく顕著に認められる。

さらに, 高さ方向で装入原料 $\mathrm{Cl}$ 成分を偏在させた実験 結果を Fig. 4 に示す。下層部原料に $\mathrm{Cl}$ 成分を偏在させた ケースは均一分布のケースよりも，焼結ケーキ下層 $\mathrm{Cl}$ 濃 度は高くなりケーキ高さ方向の $\mathrm{Cl}$ 濃度差が拡大する傾向 にある。一方，上層部原料に $\mathrm{Cl}$ 成分を偏在させたケース は均一分布のケースよりも, ケーキ上層 $\mathrm{Cl}$ 濃度は高くな り，ケーキ高さ方向の $\mathrm{Cl}$ 濃度差が小さくなる傾向にある。 


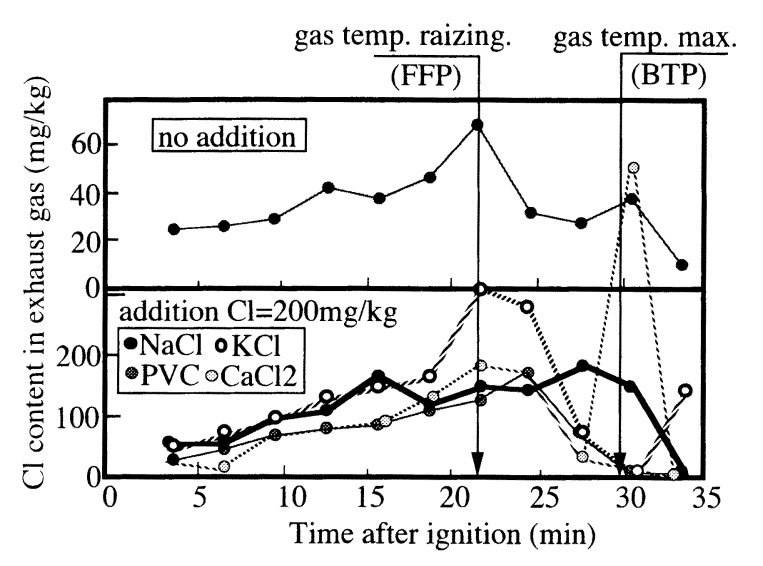

Fig. 5. Change of $\mathrm{Cl}$ content in exhaust gas by $\mathrm{Cl}$ addition to sinter mixture.

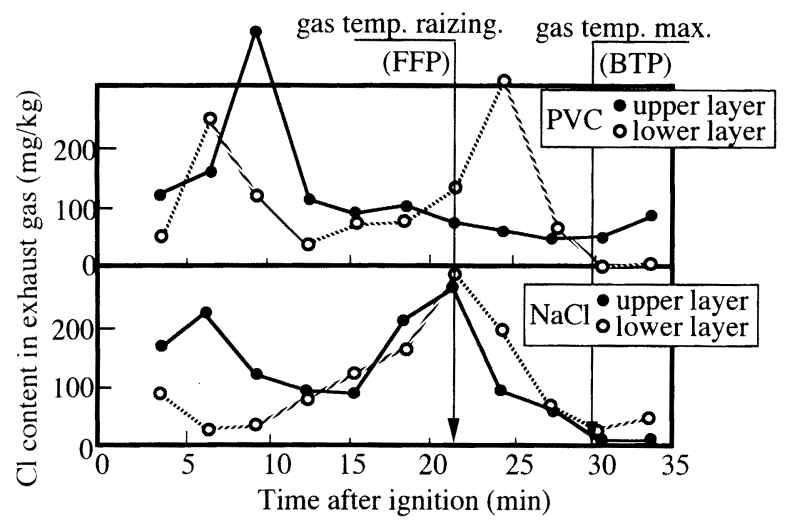

Fig. 6. Change of $\mathrm{Cl}$ content in exhaust gas by $\mathrm{Cl}$ segregation in vertical direction.

\section{$3 \cdot 3$ 排ガスCl成分濃度の時間変化}

Fig. 5 に採取ガス瓶を $3 \mathrm{~min}$ 間隔で交換して排ガス中の $\mathrm{Cl}$ 量を測定した結果を示す。排ガス中の $\mathrm{Cl}$ 濃度は焼成開始 直後から，排ガス温度立ち上がり時刻(FFP: Flame Front Point)まで単調に増加し, それ以降は減少する傾向で, 排 ガス温度最大時刻(BTP: Burn Through Point)で検出されな くなる。なお，一部 25 35 minに高濃度測定值が存在する が, これらは鍋実験において, 採取排ガス中の塩素形態の 主体が塩化物ダストであること，および鍋風箱や配管内で $\mathrm{Cl}$ 成分が残留し, 後半部の排ガス温度上昇とともに揮散 する, いわゆるメモリー効果があること ${ }^{2} に$ 起因したノイ ズと思われる。

さらに, 高さ方向で装入原料に $\mathrm{Cl}$ 成分偏在をつけた実 験結果を Fig. 6に示す。上層部原料にCl成分を偏在させた 場合は, 上層部が高温状態にある時刻で排ガス $\mathrm{Cl}$ 成分值 は高くなり，一方，下層部原料に $\mathrm{Cl}$ 成分を偏在させた場 合は, 下層部が高温状態にある時刻で排ガス $\mathrm{Cl}$ 成分值が 高くなった。

\section{4 焼結鍋中断試験における原料層および焼結ケーキの $\mathrm{Cl}$ 量}

鍋装入原料量から回収原料量を控除して求めた焼成量の

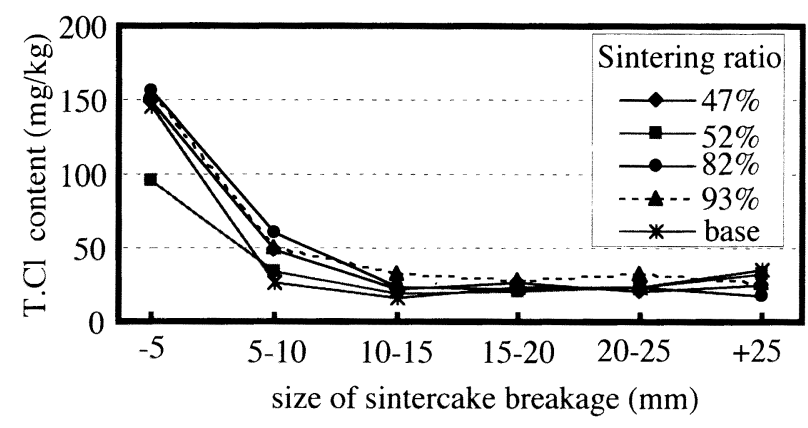

Fig. 7. $\mathrm{Cl}$ content by particle size after sintercake crushing at interrupted pot test.

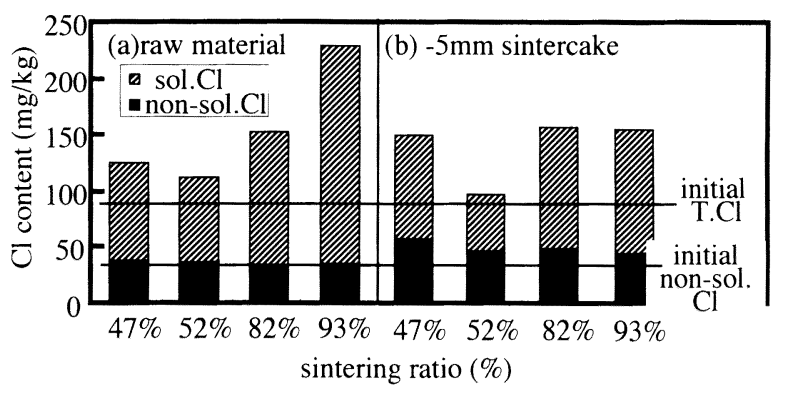

Fig. 8. $\mathrm{Cl}$ content in raw material and $-5 \mathrm{~mm}$ sintercake breakage at interrupted pot.

鍋装入原料量に対する比率を焼成率(Sintering Ratio)と定義 して中断時期を示す。Fig. 7 に焼結ケーキ破砕物における 粒度別の T.Cl成分值を示す。焼成率を変更しても各粒度別 の T.Cl值に差はないが, 返鉱となる $5 \mathrm{~mm}$ 以下において鍋 装入時原料の $90 \mathrm{mg} / \mathrm{kg}$ よりも高い $150 \mathrm{mg} / \mathrm{kg}$ を示す。5 10 $\mathrm{mm}$ でもやや值が高く, $10 \mathrm{~mm}$ 以上では $20 \sim 30 \mathrm{mg} / \mathrm{kg}$ と なっている。Fig. 8 には, 回収原料および $5 \mathrm{~mm}$ 以下破砕 ケーキの Cl定量值を示す。焼成率によらず, 回収原料の $\mathrm{T} . \mathrm{Cl}$ は鍋装入時原料值よりも上昇している。上昇 $\mathrm{Cl}$ は水溶 $\mathrm{Cl}$ が主体で, その值は平均で中断時期における揮散 $\mathrm{Cl}$ 量 の $30 \mathrm{mass} \%$ 程度に相当する。また， $5 \mathrm{~mm}$ 以下の破砕ケ一 キの T.Cl值が高いのも水溶 $\mathrm{Cl}$ に起因する割合が高い。

\section{$3 \cdot 5$ 排ガスダイオキシン濃度に影響を及ぼす要因}

\section{(1) 添加試薬 $\mathrm{Cl}$ 量の変更実験}

配合原料への添加 $\mathrm{Cl}$ 量を変更した実験の排ガス中 P5CDFs 濃度を Fig. 9に示す。 $\mathrm{NaCl}$ 水溶液, PVCポリマー 試薬のいずれも添加量に比例してP5CDFs濃度は増加して いる。この結果から, 配合原料中の $500 \mathrm{mg} / \mathrm{kg}$ 程度の $\mathrm{Cl}$ 成 分は有機物, 無機物によらず, 排ガスダイオキシン濃度を 上昇させる。

\section{(2) 添加 $\mathrm{Cl}$ 試薬種類の変更実験}

配合原料に添加する $\mathrm{Cl}$ 試薬種類を変更した実験の排ガ ス中 P5CDFs 濃度を Fig.10に示す。同一 $\mathrm{Cl}$ 濃度では $\mathrm{KCl}$ が 最も高く, $\mathrm{PVC}, \mathrm{NaCl}, \mathrm{CaCl}_{2}$, 高 $\mathrm{Cl}$ 鉄鉱石の順番になって いる。また, 圧延油との混合効果を調査したケースでは, ベース配合および $\mathrm{NaCl}$ 添加のいずれの場合も，圧延油添 


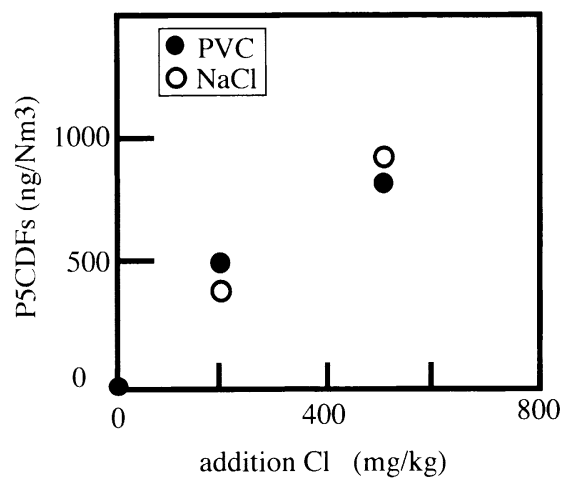

Fig. 9. Effect of addition $\mathrm{Cl}$ to mixture on dioxins concentration in exhaust gas.

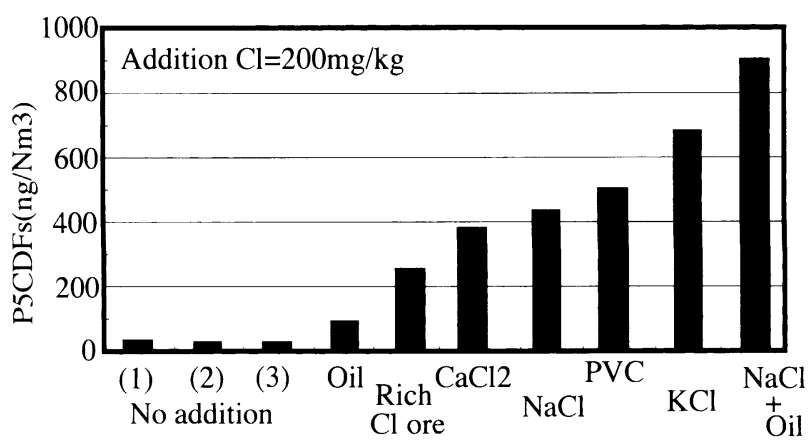

Fig. 10. Effect of addition $\mathrm{Cl}$ source to mixture on dioxins concentration in exhaust gas.

加により P5CDFs 濃度が上昇している。

(3) 高さ方向の $\mathrm{Cl}$ 成分偏在実験

全添加試薬 $\mathrm{Cl}$ 量が等しい前提で, $\mathrm{Cl}$ 添加濃度の分布が 均一である実験の排ガス中 P 5 CDFs 濃度を分母に, 上層ま たは下層に偏在させた実験の排ガス中 P 5 CDFs 濃度を分子 にとり，その影響を倍率で評価した結果をFig.11に示す。 上層部への添加 $\mathrm{Cl}$ 試薬の偏在は $\mathrm{P} 5 \mathrm{CDFs}$ 濃度を上昇させる 傾向にあるが，下層部への添加 $\mathrm{Cl}$ 試薬の偏在は $\mathrm{P} 5 \mathrm{CDFs}$ 濃 度には大きな影響を及ぼさない。

\section{4. 考察}

\section{$4 \cdot 1$ 焼結層内における Cl成分の挙動}

一般に焼結過程においては，装入原料は $60 \sim 70^{\circ} \mathrm{C}$ で飽 和蒸気を含む焼成ガスにさらされ水分が凝集したのち（湿 潤帯), 急速な昇温過程での水分乾燥を経て (乾燥帯), コークス燃焼が起こり $1100 \sim 1350^{\circ} \mathrm{C}$ の焼結化反応後（燃 焼帯)，冷却され焼結ケーキが形成される(冷却帯)。この 高温の燃焼帯は数分程度であるが，原料中に含まれる $\mathrm{Cl}$ 成分を気体または微粒ダストとして焼成ガスに揮散させ る。これを焼結層からみると上から下に向かって, 冷却帯, 燃焼帯, 乾燥帯, 湿潤帯と並ぶ。燃焼帯で揮散した $\mathrm{Cl}$ 成 分は乾燥帯や湿潤帯で一部吸着され，吸着されないものが

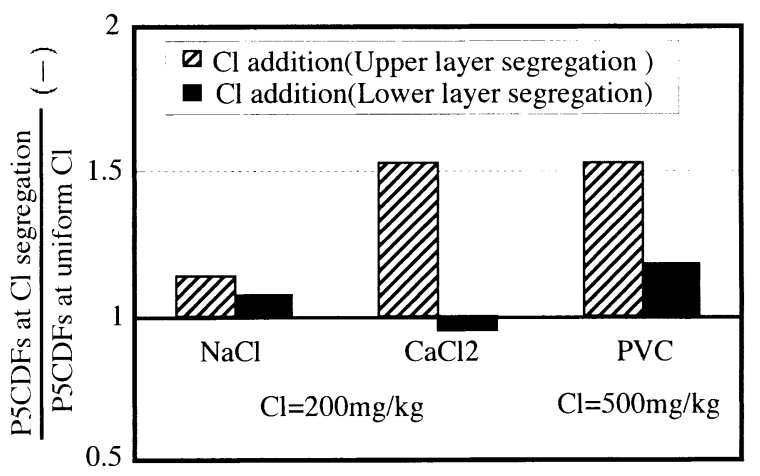

Fig. 11. Effect of $\mathrm{Cl}$ segregation in sinter bed in vertical direction on dioxins concentration in exhaust gas.

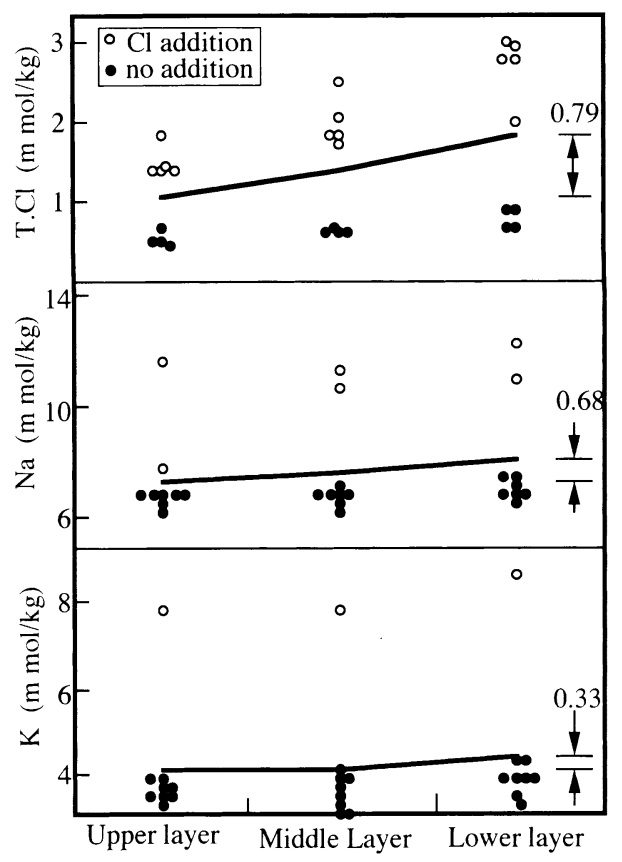

Fig. 12. $\mathrm{K}, \mathrm{Na}$ and $\mathrm{Cl}$ contents in sintercake along vertical direction of sintering bed.

排ガスとして排出される。

さて，焼結層ではコークスの燃焼進行にともない燃料の 燃焼熱が下層に蓄積され，上層よりも下層ほど熱条件（最 高温度，高温時間）が大きい。したがって，熱条件的には 下層ほど $\mathrm{Cl}$ 成分は揮散しやすく $\mathrm{Cl}$ 成分は低いはずである が，Fig. 3の結果は逆になっている。そこで，Na，K成分に ついても同様の定量を行い, 各層の $\mathrm{Na}, \mathrm{K}, \mathrm{Cl}$ 元素のモル 濃度を Fig.12に示す。定量值が微量であるため, 全測定値 の平均値で整理すると, $\mathrm{Cl}$ 同様に $\mathrm{Na}$ および $\mathrm{K} も$ 上層より も下層が大きい傾向が認められ，さらにNa成分上昇分と $\mathrm{K}$ 成分上昇分の合計モル值はほぼ $\mathrm{Cl}$ 成分上昇分のモル值と 等しく，濃度上昇した $\mathrm{Cl}$ 成分と $\mathrm{Na}, \mathrm{K}$ 成分は関連した挙動 をしているものと思われる。

揮散 $\mathrm{Cl}$ 量の排ガス定量は精度的に困難がともなうの で2), 配合原料 $\mathrm{Cl}$ 量から焼結ケーキ $\mathrm{Cl}$ 量を控除した值を揮 散 $\mathrm{Cl}$ 量と定義して，採取排ガス $\mathrm{Cl}$ 量との対応を調査した。 


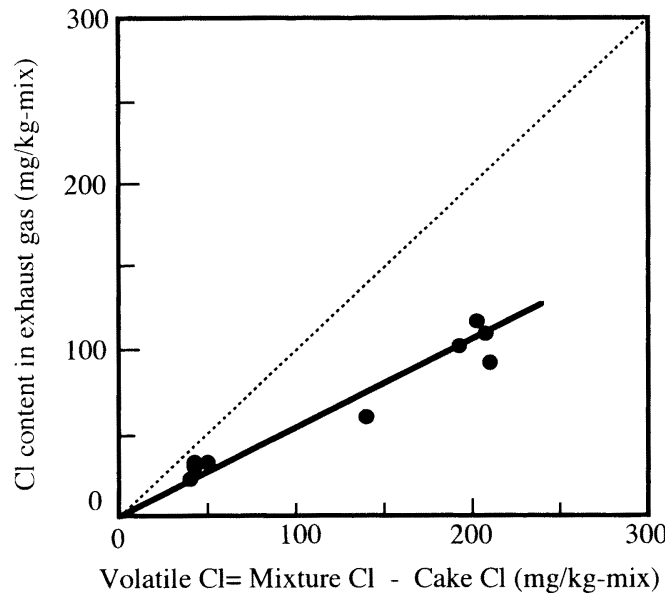

Fig. 13. Relation between $\mathrm{Cl}$ content in exhaust gas and volatile $\mathrm{Cl}$ content in sinter bed.

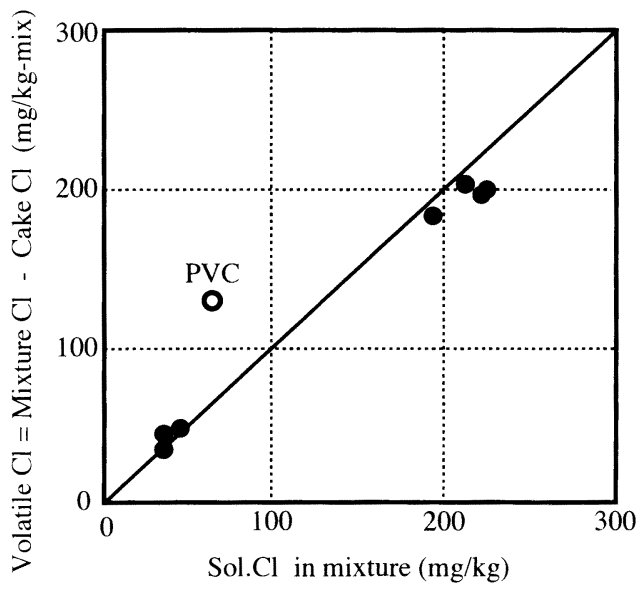

Fig. 14. Relation between sol.Cl content in sinter mixture and volatile $\mathrm{Cl}$ content in sinter bed.

結果を Fig.13に示す。バランス上, 風箱内残留物および配 管付着と思われる不明分が存在するので, 計算揮散 $\mathrm{Cl}$ 量 と採取排ガス $\mathrm{Cl}$ 量は一致しないが，比例関係が認められ る。Fig. 5の結果によれば，焼結開始から排ガス Cl成分が 検出されて打り，揮散 $\mathrm{Cl}$ 成分は焼結原料層に吸収されな いものが存在する。この傾向は Fig. 6 の Cl成分偏在試験に おける高 $\mathrm{Cl}$ 原料部が燃焼带に位置した時刻において排力゙ ス $\mathrm{Cl}$ 成分值が上昇した結果からもうかがえる。そして， Fig. 5 に示される焼成時刻の経過（燃焼帯の降下）にとも なって排ガス $\mathrm{Cl}$ 成分值が増加していく結果と, Fig. 3 の焼 結ケーキ残留 $\mathrm{Cl}$ 成分值も下層側ほど増加していく結果は， 燃焼帯での揮散 $\mathrm{Cl}$ 量が時刻経過にともなって增加してい ることを示している。焼結前の装入原料 $\mathrm{Cl}$ 濃度が一定な ので, これら2つの結果から, 原料 $\mathrm{Cl}$ 成分は燃焼帯で揮散 し，焼成ガスに含有され下層側に移動したものと考えられ， Fig. 8の中断試験の回収原料 $\mathrm{Cl}$ 值の上昇結果もこれらを亭 づけている。

Fig. 14には配合原料の水溶 $\mathrm{Cl}$ 濃度と揮散 $\mathrm{Cl}$ 量との対応 を示す。PVC添加結果を除いた無機塩化物添加について,
良好な数值的一致が認められる。添加した試薬の $\mathrm{NaCl}$, $\mathrm{KCl}, \mathrm{CaCl}_{2}$ の水に対する溶解度が高いのに対し，PVCは水 には溶解しない。一方，燃焼帯では約 $1300^{\circ} \mathrm{C}$ まで加熱さ れ，Fig.14での数值的一致は，概略，通常の配合原料中の 水溶 $\mathrm{Cl}$ は焼結過程で揮散するのに対し，非水溶 Ciは焼結 ケーキに残留する傾向が強いことを示唆する。なお，PVC 添加ケースにおいて，水溶 $\mathrm{Cl}$ 量が低いにもかかわらず揮 発 $\mathrm{Cl}$ 量が高い理由については，PVCのような有機 $\mathrm{Cl}$ は非 水溶 $\mathrm{Cl}$ ではあるが，焼結過程に打いて低温で熱分解し $\mathrm{HCl}$ となって挙動するためと思われる。

Fig. 8の中断試験結果における原料層および $5 \mathrm{~mm}$ 以下焼 結ケーキの $\mathrm{Cl}$ 上昇分が水溶 $\mathrm{Cl}$ 主体であったことは，揮散 $\mathrm{Cl}$ の原料層への吸着による上:型を示唆している。細谷ら

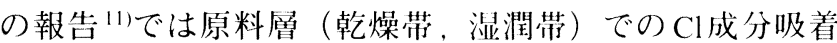
比率を明確にしていないが，乾燥带での吸着が高く湿潤帯 での吸着は少ない結果を示している。葛原らの報告12では 飽和水蒸気下での $\mathrm{HCl}$ ガスは, $19 \mathrm{~mm}$ 層厚の模擬原料湿潤 層通過時における湿潤層での吸着率が $60 \mathrm{mass} \%$ 程度であ る結果を示して打り，100 mm 程度の原料湿潤帯でほぼ全 量吸着されると解勫できる。

Fig. 7 における $5 \mathrm{~mm}$ 以下の破砕焼結ケーキの $\mathrm{Cl}$ 成分濃 度が装入時原料の $\mathrm{Cl}$ 成分濃度よりも䯩い結果は， $5 \mathrm{~mm}$ 以 下破砕ケーキは焼結ケーキ層のガス接触表面部に位置し破 砕片となったものが多く|31ケーキ表面でのCl成分吸着も 存在することを示唆する

以上の結果から総合的に考えれば，原料中の Cl成分は 湿潤带，乾燥帯では揮散せず、コークス燃焼温度以上の高 温度状態で $\mathrm{KCl}, \mathrm{NaCl}, \mathrm{CaCl}_{2}$ などの金属塭化物として部分 的に揮発し，燃焼帯の焼結ケーキ表面打よび乾燥带原料粒 子表面に吸収されるが，温度が低下すると塩化物気体は微 細ダストとなり湿潤帯では吸着されずに排ガスに放出され るのではないかと思われる。もちろん，焼結のような短時 間反応では原料中のすべてのCl成分が揮散するわけでな く，本実験結果の平均としては約 $30 \mathrm{mass} \%$ が焼結ケーキ に残留し，燃焼前面（燃焼带と乾燥带の境界面）を通過す る揮散 $\mathrm{Cl}$ の $30 \mathrm{mass} \%$ が原料層に吸着され，残る 70 mass $\%$ が直接，排ガスとして放出された。

\section{$4 \cdot 2 \mathrm{Cl}$ 成分と排ガスダイオキシン濃度との関係}

Fig. 9 と Fig.10の結果からダイオキシン発生は原料 $\mathrm{Cl}$ 量 およびその含有化合物形態の両方に影響を受けると言え る。また，原料中の油分の存在はダイオキシン発生を加速 させていると解釈できる。添加 $\mathrm{Cl}$ 化合物形態を変更した Fig.10の実験結果について，排ガス中 $\mathrm{Cl}$ 成分濃度と P5CDFs濃度の関係を調查した。結果をFig.15に示すが， 圧延油やPVCなどの有機成分を添加したグループを層別 すると，良好な対応が認められた。この結果から焼結層ダ イオキシン生成においては，原料中の $\mathrm{Cl}$ 成分ではなく揮 散する $\mathrm{Cl}$ 成分や油分が深く関連していると推察される。 


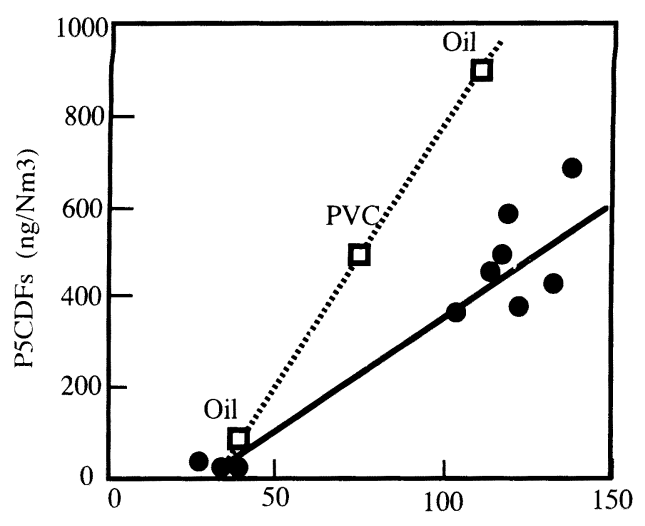

$\mathrm{Cl}$ content in exhaust gas $(\mathrm{mg} / \mathrm{Nm} 3)$

Fig. 15. Relation between $\mathrm{Cl}$ content and dioxins concentration in exhaust gas.

Fig.11の高さ方向 $\mathrm{Cl}$ 偏在実験における上層への Cl成分 の偏在は, 最終の焼結ケーキ残留 $\mathrm{Cl}$ 成分值が等しくても, 上層側にある $\mathrm{Cl}$ 成分ほど揮散と吸着を繰返す機会が多く なり下層側にある $\mathrm{Cl}$ 成分よりもダイオキシン生成量が増 加するものと考える。しかし，下層への Cl成分偏在は， 逆にダイオキシン生成量が低下するはずであるが，結果は 異なる。この原因として，焼結工程では下層部の下側に床 敷層が存在し，この床敷層がダイオキシン生成に関与して いると考えれば，下層への $\mathrm{Cl}$ 偏在はダイオキシン生成を 増加させる可能性もあり, 今後の検討課題である。

Fig.10での $\mathrm{KCl}, \mathrm{NaCl}, \mathrm{CaCl}_{2}$ のダイオキシン濃度の順 番は, 揮散 $\mathrm{Cl}$ 量の順番に対応しており熱力学的にも説明

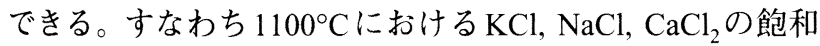
蒸気压を示すと, 各々 $6.6 \mathrm{kPa}, 3.0 \mathrm{kPa}, 0.026 \mathrm{kPa}$ となってお り, $\mathrm{KCl}, \mathrm{NaCl}, \mathrm{CaCl}_{2}$ の順番で揮発しやすい。また, Fig. 5 に見られるごとく $\mathrm{PVC} と \mathrm{CaCl}_{2}$ 添加ケースの排ガス $\mathrm{Cl}$ 成分 は類似の挙動をしている。この結果から，PVCが有機物 で比較的低温で熱分解し $\mathrm{HCl}$ を生成させるが, 原料帯（乾 燥帯, 湿潤帯) で吸収され, 焼結層内に存在する十分な $\mathrm{Ca}^{2+}$ イオンと反応してから燃焼帯で $\mathrm{CaCl}_{2}$ として揮散する ものと思われる。そして，Fig.15に示されるようにPVC添 加ケースの揮散 $\mathrm{Cl}$ 量( $\square \mathrm{PVC})$ は $\mathrm{KCl}, \mathrm{NaCl}, \mathrm{CaCl}_{2}$ 添加ケー スのそれ(の)よりも低い。しかし，PVC添加のダイオキシ ン濃度が無機塩化物添加のそれよりも高いのは, Fig.15の 圧延油添加結果にも見られるように, 熱分解で生成した有 機分によりダイオキシン生成が加速されたためと思われ る。また，高 $\mathrm{C}$ 鉄鉱石のダイオキシン濃度が低いのは, 水溶 $\mathrm{Cl}$ 比率が低いことから鉄鉱石中の $\mathrm{Cl}$ 成分が $\mathrm{NaCl}, \mathrm{KCl}$, $\mathrm{CaCl}_{2}$ 試薬水溶液の $\mathrm{Cl}$ 成分よりも揮散しにくいためと思わ れる。

しかし，鉄鉱石 $\mathrm{Cl}$ 成分の焼結過程におけるダイオキシ ン生成への関与が小さいとしても，この鉄鉱石 $\mathrm{Cl}$ 成分は 焼結工程, 高炉工程において揮散しやすい $\mathrm{Cl}$ 成分に改質 され，返鉱および回収ダストとして再び焼結原料に循環さ
れれば，間接的に高い関与をあたえ，最終評価にあたって はFig.10の結果を修正する必要があると考える。すなわち， 焼結過程における原料銘柄のダイオキシン生成評価は, $\mathrm{Cl}$ 成分の焼結過程外の循環状況も考慮して行う必要がある。

\section{5. 結言}

焼結原料に $\mathrm{Cl}$ 成分を添加した焼結鍋試験を実施し以下 の結果を得た。

（1）焼結原料中の微量 $\mathrm{Cl}$ 成分は約 20 40 mass \% が焼結 ケーキに残留し，揮散 Cl成分の 20 40 mass\% が下方に位 置する原料層に吸着され，残る $60 \sim 80 \mathrm{mass} \%$ が直接，排 ガスとして放出される。吸着 $\mathrm{Cl}$ 成分は原料層の焼結化に ともない残留または揮散を繰返し下方に移動していく。揮 散 $\mathrm{Cl}$ 成分としては $\mathrm{KCl}, \mathrm{NaCl}$ などの無機金属塩化物が主体 と思われる。

（2）焼結排ガスダイオキシン濃度は， $500 \mathrm{mg} / \mathrm{kg}$ までの 範囲において添加 $\mathrm{Cl}$ 量に正比例した。また，等添加 $\mathrm{Cl}$ 量 であっても Cl含有化合物形態の影響を受け，高いものか $ら \mathrm{KCl}$, 塩化ビニールポリマー, $\mathrm{NaCl}, \mathrm{CaCl}_{2}$, 鉄鉱石 $\mathrm{Cl}$ あった。この影響関連因子として, 揮散 $\mathrm{Cl}$ 成分と原料有 機成分が挙げられた。さらに，上層に高 $\mathrm{Cl}$ 成分を偏在さ せたケースは均一分布のケースに比べ排ガスダイオキシン 濃度は上昇したが，下層に高 $\mathrm{Cl}$ 成分を偏在させたケース は均一分布のケースと差がなかった。

本研究の一部は，(財）鉄鋼業環境保全技術開発基金の 大規模研究助成金によってなされたものであることを付記 する。また, 本研究実施にあたり, 多大なるご支援, ご指 導を給わった焼結ダイオキシン類低減研究会の各位に謝意 を表します。

\section{文献}

1) Y.Hosotani, M.Nakano, T.Kawaguchi, K.Sato, M.Miyagawa and K.Nushiro: CAMP-ISIJ, 13 (2000), 69.

2 ) T.Kawaguchi and M.Matsumura: Tetsu-to-Hagané, 88 (2002), 16.

3 ) Y.Iritani and T.Fukuda: Tetsu-to-Hagané, 56 (1970), S32.

4 ) K.Kobayashi, Y.Miura and A.Okamoto: Tetsu-to-Hagané, 65 (1979), 1355.

5 ) K.Narita, M.Maekawa, H.Kanayama, H.Yamaguchi, C.Nagai, K.Tanaka and K.Yoshioka: Tetsu-to-Hagané, 66 (1980), S44.

6 ) H.Kanayama, Y.Seki, T.Saito, M.Maekawa and K.Narita: Tetsu-toHagané, 67 (1981), S686.

7 ) C.Nagai, K.Tanaka, K.Yoshioka, K.Narita, M.Maekawa and H.Kanayama: Tetsu-to-Hagané, 66 (1980), S676.

8 ) C.Nagai, K.Tanaka, T.Uehara, K.Yoshioka and K.Suwashita: Tetsuto-Hagané, 66 (1980), S677.

9 ) K.Tanaka, T.Uehara, J.Jinno, K.Yoshioka and M.Kono: Tetsu-toHagané, 67 (1981), S687.

10) N.Taguchi, T.Otomo, K.Tasaka and Y.Omori: Tetsu-to-Hagané, 73 (1987), 1909.

11) Y.Hosotani, M.Nakano, E.Kasai, H.Noda and Y.Tomita: CAMP-ISIJ, 13 (2000), 796.

12) S.Kuzuhara, T.Nakamura, E.Kasai and H.Noda: CAMP-ISIJ, 14 (2001), 117.

13) T.Kawaguchi and K.Kuriyama: Tetsu-to-Hagané, 78 (1992), 1077. 